\title{
Spatial Analysis of Breeding Place and Larva Density Existence with DHF (Dengue Hemorrhagic Fever) Incidence Rate in Pringsewu District, Indonesia
}

\author{
Yuliana Nina Yuanita*, Onny Setiani, Nur Endah Wahyuningsih
}

Masters in Environmental Health, University of Diponegoro - Semarang, Indonesia

*Corresponding Author: yuliananina19@yahoo.com

\begin{abstract}
Dengue Hemorrhagic Fever (DHF) is a type infectious disease that often causes extraordinary events in Indonesia. Pringsewu District is one area that has experienced an increase in dengue cases every year. One of the risk factors for the occurrence of DHF is the presence of breeding places and vector density. Vector density can be measured through ABJ, HI, and CI values. This research aims to determine the region's level of vulnerability against DHF incidents, the relationship of Breeding Place existence, ABJ, HI and CI with DHF incidents in Pringsewu District. This research uses an observational analytic method with a cross sectional approach, data are analyzed using overlay map and correlation statistical tests. The results showed that there was a relationship between breeding place $(p=0,000), A B J(p=0,000), H I(p=0,000)$, and $C I(p=0,000)$ with the incidence of $D H F$.
\end{abstract}

Keywords - DHF, breeding place, ABJ, CI, HI.

\section{INTRODUCTION}

Dengue Hemorrhagic Fever (DHF) is an infectious disease caused by dengue virus that belongs to the genus Flavivirus and Flaviviradae family and its transmission occurs through the bite of Aedes mosquitos, especially Aedes aegypti species. ${ }^{1}$ Cases of DHF in Indonesia were first reported in the city of Surabaya, in 1968. Since the beginning of the DHF case was discovered until 2015 there has been a significant increase in the number of provinces and districts/cities that have DHF cases. In 1968, only 2 provinces and 2 cities that had DHF cases, but in 2015 it increased to 34 provinces and 436 districts/cities that had DHF cases. ${ }^{2}$

The number of DHF cases in Lampung Province tends to fluctuate each year. Based on the number of DHF cases per year, it is known that three districts/cities with the highest number of DHF cases in Lampung Province are Metro City, Pringsewu Districts and Bandar Lampung City. ${ }^{3}$ Pringsewu District is one of the dengue endemic districts in Lampung Province. The number of DHF cases in Pringsewu District during the last five years has always been above the national target of DHF cases, which is less than 49 per 100.000 population. ${ }^{4}$

The DHF control target that has been set by WHO is to reduce the mortality and morbidity due to DHF by $50 \%$ in
2020. In order to achieve this target, strategies that must be implemented include sustainable vector control. ${ }^{5,6}$ In implementing sustainable vector control, sustainable epidemiology data are needed so that data analysis can be done both temporally and spatially. Spatial analysis is used to map epidemiological, entomological and environmental stratification. Spatial analysis is useful for stratifying the area based on the characteristics of larval habitat in the area, so that it can help to determine the appropriate vector control efforts and can reduce the occurrence of outbreaks. $^{7}$

Spatial analysis was obtained using the data of Geographical Information System (GIS). Spatial analysis is done by overlaying or combining data from two or several initial maps so that a new map is produced from the analysis. ${ }^{8}$ GIS capabilities can be used for DHF vector observations that can provide information about areas that are vulnerable to DHF cases. ${ }^{9}$

Based on this, the researcher is interested in finding out the region's level of vulnerability to the incidence of DHF, the relationship of the Breeding Place existence, $\mathrm{ABJ}, \mathrm{HI}$ and CI with the incidence of DHF in the Pringsewu District which is a DHF endemic area. In obtaining a description of areas that are vulnerable to DHF, a spatial analysis is carried out on areas vulnerable to DHF cases, so as to 
determine operational steps in the prevention and eradication of DHF.

\section{MATERIAL AND METHOD}

The research design is analytic observational with Cross Sectional approach. The use of GIS is done to identify and analyze the occurrences of DHF, the existences of larvae Ae. aegypti and the region's vulnerability level to the occurrences of DHF, so that it can be explained visually about the environmental conditions that affect the occurrences of DHF as well as vulnerable areas of DHF cases. Correlation test is performed to determine the relationship between the independent variables and the dependent variables.

The population in this study is the population of the area (Area Population) in the work area in the Pringsewu District Health Office. All cases of DHF in February March 2019 were studied (total population). DHF cases are the number of the DHF occurrences in the Pringsewu District Health Office in February -March 2019.

The research instruments used were, a map of the Pringsewu District Health Office area, DHF victims data forms, larva surveying tools, Global Positioning System (GPS) Test, and GIS software.

\section{RESULTS}

Pringsewu District has 9 sub-district territories consisting of Pagelaran, North Pagelaran, Pringsewu, Banyumas, Sukoharjo, Adiluwih, Gadingrejo, Ambarawa, and Pardasuka. The area of Pringsewu District is $625 \mathrm{~km}^{2}$ with altitudes between 100 - 200 meters above sea level.

Table 1: Frequency Distribution of Breeding Place Types

\begin{tabular}{lrrrr}
\hline \multirow{2}{*}{ Breeding Place Types } & \multicolumn{5}{c}{ Total } \\
\cline { 2 - 5 } 1. Inside the House & \multicolumn{1}{c}{ Checked } & Positive & \multicolumn{1}{c}{$\%$} \\
Bathtub & 795 & 32,02 & 180 & 54,22 \\
Plastic Bucket & 1.620 & 65,24 & 126 & 37,95 \\
Dispenser Reservoir & 68 & 2,74 & 26 & 7,83 \\
Total & $\mathbf{2 . 4 8 3}$ & $\mathbf{1 0 0 , 0 0}$ & $\mathbf{3 3 2}$ & $\mathbf{1 0 0 , 0 0}$ \\
2. Outside the House & & & & \\
Used tires & 109 & 19,02 & 29 & 28,16 \\
Secondhand goods & 51 & 8,90 & 11 & 10,68 \\
Water Vessel & 66 & 11,52 & 6 & 5,83 \\
Plastic waste & 144 & 25,13 & 37 & 35,92 \\
Bird Drinking Places & 142 & 24,78 & 19 & 18,45 \\
Fish pond & 61 & 10,65 & 1 & 0,97 \\
Total & $\mathbf{5 7 3}$ & $\mathbf{1 0 0 , 0 0}$ & $\mathbf{1 0 3}$ & $\mathbf{1 0 0 , 0 0}$ \\
Natural & & & & \\
Bamboo Pieces & 275 & 29,30 & 88 & 80,00 \\
Coconut Shell & 355 & 38,34 & 4 & 3,64 \\
Chocolate Shell & 296 & 31,97 & 18 & 16,36 \\
Total & $\mathbf{9 2 6}$ & $\mathbf{1 0 0 , 0 0}$ & $\mathbf{1 1 0}$ & $\mathbf{1 0 0 , 0 0}$ \\
\hline
\end{tabular}

Based on Table 1, it is known that the highest percentage of breeding place inside the house is plastic bucket $(65,24 \%)$, the highest percentage of breeding place outside the house is plastic waste $(25,13 \%)$, the highest percentage of natural breeding place is coconut shell $(38,34 \%)$. While the highest percentage of positive breeding place inside the house is bathtub $(54,22 \%)$, the highest percentage of positive breeding place outside the house is plastic waste $(35,92 \%)$ and the highest percentage of natural positive breeding place is bamboo pieces $(80,00 \%)$. 


\section{Spatial Analysis}

Based on the research conducted, the following results are obtained:

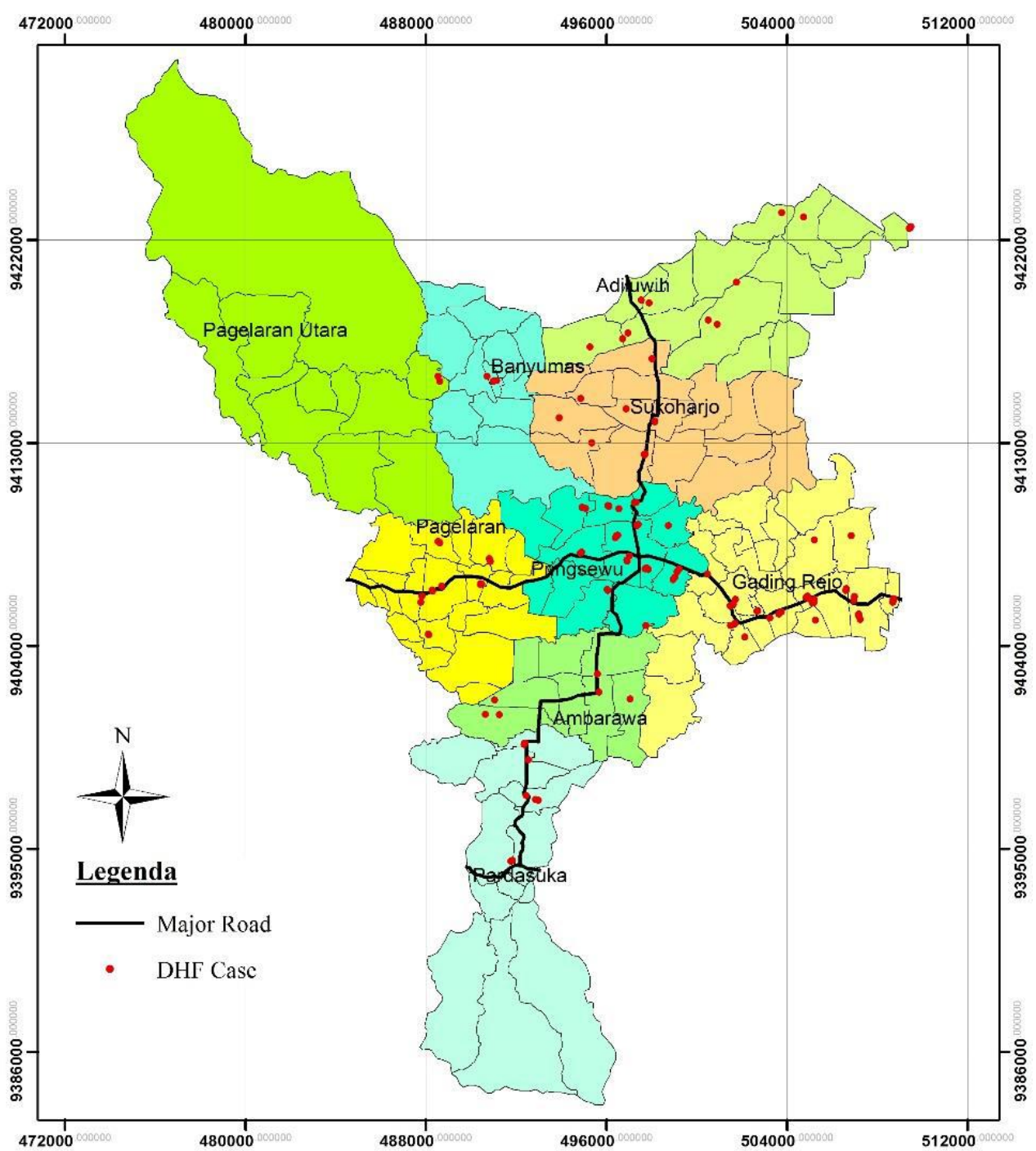

Fig. 1: Distribution of DHF Patiens in Pringsewu in February - March 2019

Based on the Average Nearest Neighbor analysis, the results show that the distribution of DHF cases in Pringsewu District has a clustered pattern with NNRatio $=0,301$ (NNRatio <1). Based on Observed Mean Distance values, obtained values 325,98 meters, meaning that in
Pringsewu District, every 325, 98 meters found one DHF victim. The distribution of DHF cases is around the main highway in Pringsewu District, especially the main road that connects Lampung Province and Bengkulu Province. 


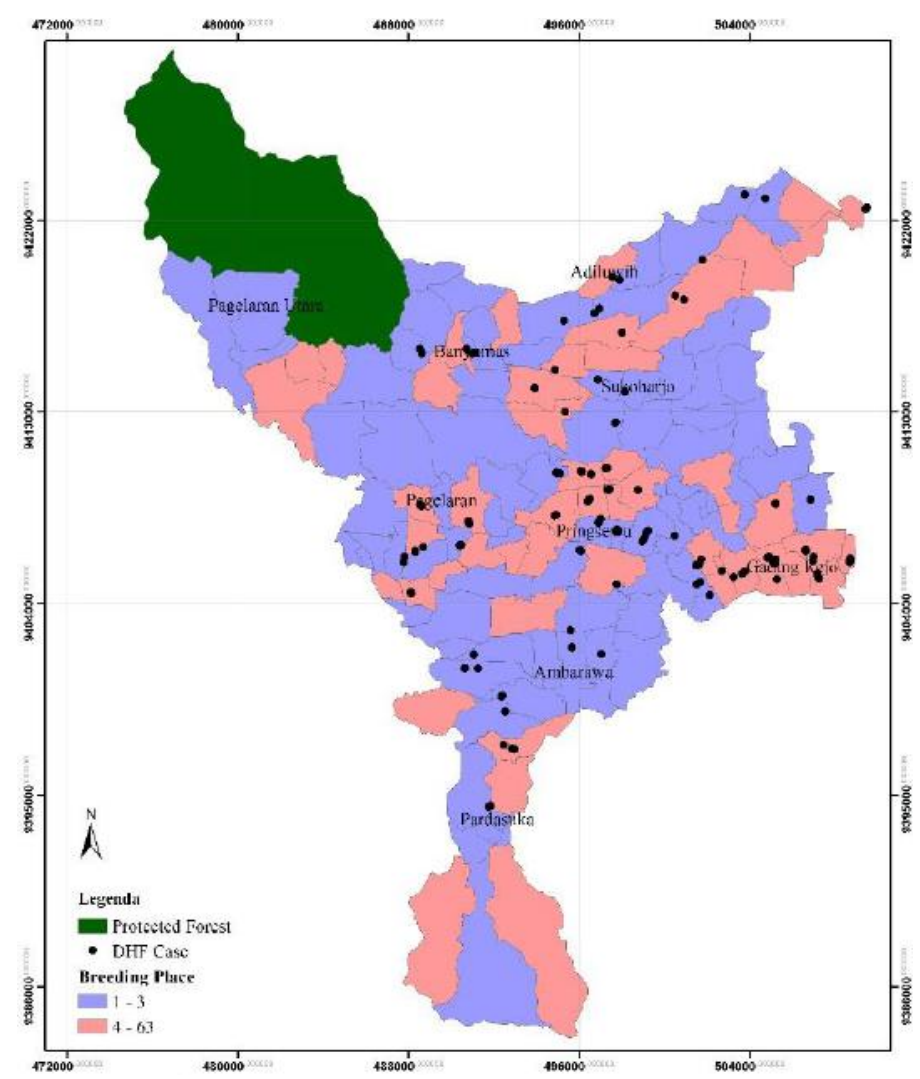

Fig 2: Map of Breeding Place and Distribution of DHF Cases

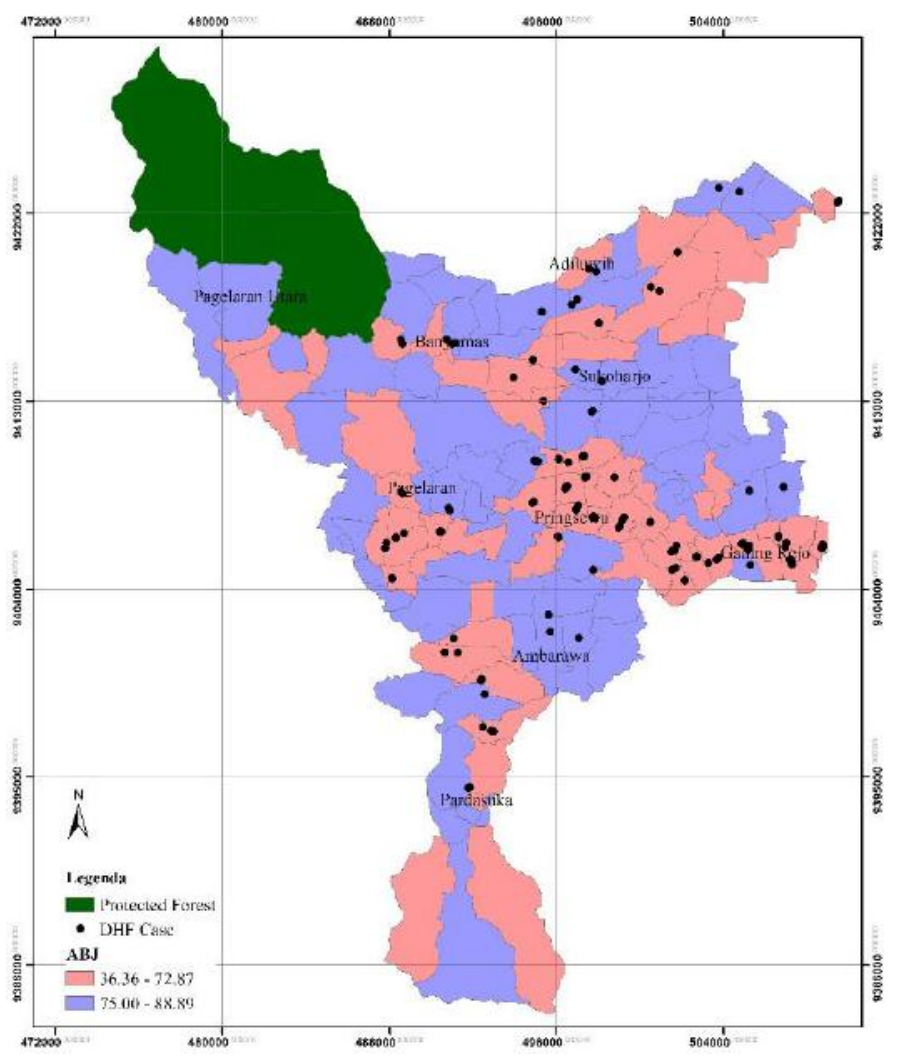

Fig. 3: Map of larvae-free numbers and Distribution of DHF Cases 


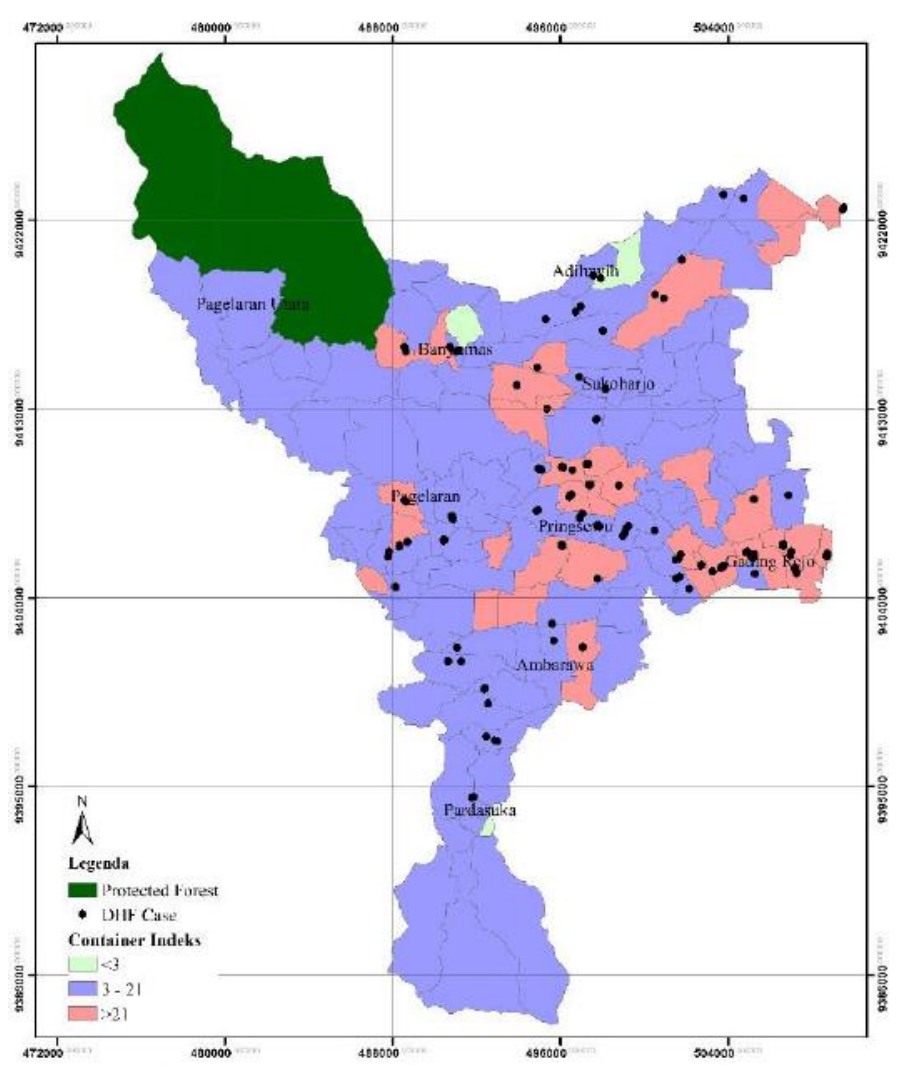

Fig. 4: Map of Container Index and Distribution of DHF Cases

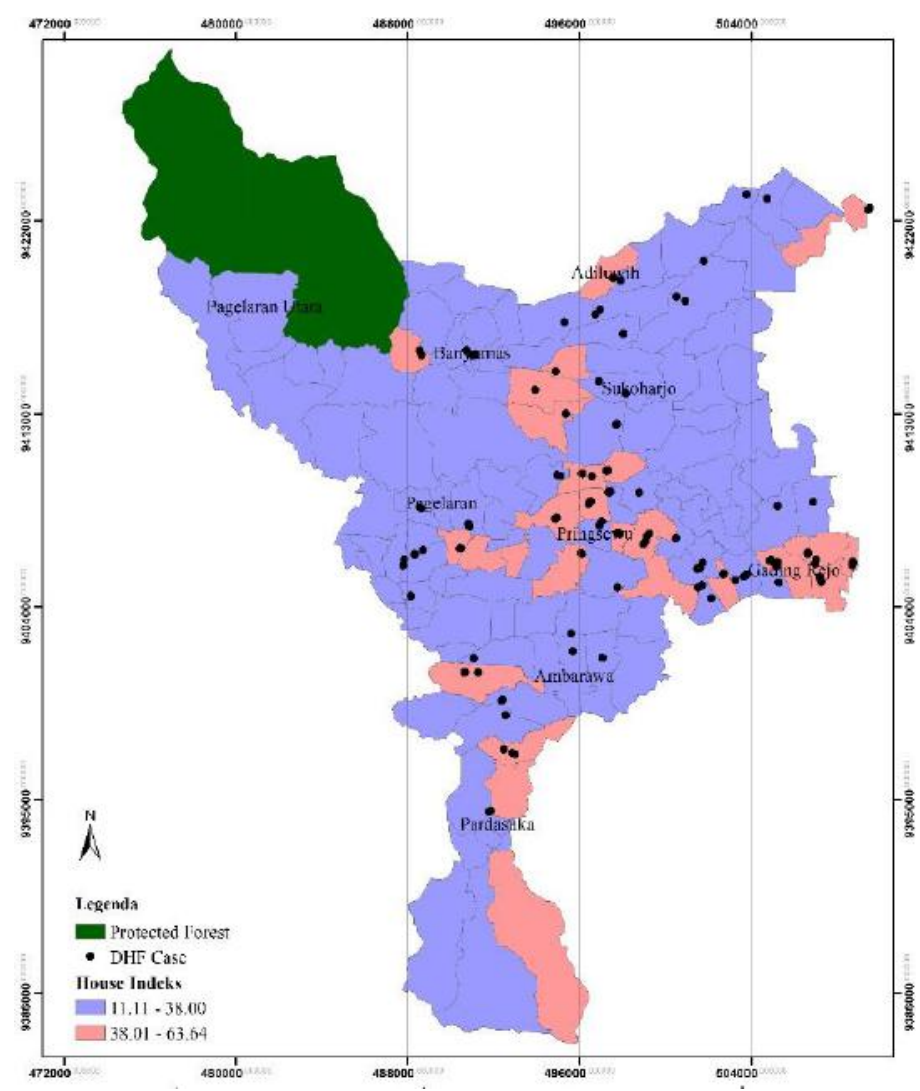

Fig. 5: Map of House Index and Distribution of DHF Cases 
Fig. 2 shows that the number of breeding place in Pringsewu District varies between $1-63$ pieces. There are many DHF cases in areas with more than 3 breeding places. Based on Fig. 3 it can be seen that there are no areas in Pringsewu District that have ABJ $>95 \%$, ABJ in Pringsewu District ranges between 36, 36\% - 88, 89\%. The pattern of DHF cases distribution in Pringsewu District is more common in areas that have low $\mathrm{ABJ}$, which is between 36, $36-72,87 \%$. CI categorization uses the Stegomyia indicator established by WHO. CI categorization is high $(\mathrm{CI}>21)$, moderate $(\mathrm{CI}=3-20)$ and low (CI <3). ${ }^{10}$ Based on Fig. 4 it can be seen that most of the areas in Pringsewu District have moderate CI and there are 2 regions that have low CI. The distribution of DHF cases in Pringsewu District is more common in areas that have high CI compared to regions that have medium or low CI. Categorizing HI uses Stegomyia indicator established by WHO. The categorization of the HI variable is as follows: high $(\mathrm{HI}>38)$, moderate $(\mathrm{HI}=4-37)$, and low $(\mathrm{HI}=1-3) .{ }^{10}$ Based on Fig. 5 , it can be seen that no region in Pringsewu District that has low HI. Most areas in Pringsewu District have moderate HI. The distribution of DHF cases in Pringsewu District is more common in areas that have high $\mathrm{HI}$ compared to regions that have moderate HI.

\section{Bivariate Analysis}

Table 2 Bivariate Analysis Results of the Correlation between Breeding Place, ABJ, Container Indeks, House Index and DHF Occurrence Rates

\begin{tabular}{|c|c|c|c|c|}
\hline Number & Variable & $\begin{array}{l}\text { Correlation } \\
\text { coefficient } \\
\text { (r) }\end{array}$ & p-value & Interpretation \\
\hline 1 & Breeding Place & 0,357 & 0,000 & The positive coefficient is weak, significant \\
\hline 2 & ABJ & $-0,441$ & 0,000 & The negative coefficient is strong, significant \\
\hline 3 & $\begin{array}{l}\text { Container } \\
\text { Index }\end{array}$ & 0,544 & 0,000 & The positive coefficient is strong, significant \\
\hline 4 & House Index & 0,441 & 0,000 & The positive coefficient is strong, significant \\
\hline
\end{tabular}

The results showed that there was a significant relationship between the total presence of Breeding Place and the DHF occurrence rate $(p$-value $=0,000)$, there was a significant relationship between $\mathrm{ABJ}$ and the $\mathrm{DHF}$ occurrence rate ( $p$-value $=0,000)$, there was a significant relationship between Container Index and the DHF occurrence rate ( $p$-value $=0,000)$ and there is a significant relationship between the House Index and the DHF occurrence rate ( $p$-value $=0,000)$.

\section{DISCUSSION}

DHF cases in February - March 2019 were 274 cases, with the occurrence rate of $68,47 / 100.000$ population. From 131 villages in Pringsewu District, 70 villages were not infected with HDF or 0 (zero) cases in February March 2019. The region with the highest number of DHF cases was Gadingrejo village with 15 DHF cases. However, the region with the highest DHF occurrence rate is East Gadingrejo village with the DHF occurrence rate of $691,82 / 100.000$ population. The occurrence of DHF in Pringsewu District for two months is already above the Minimum Service Standards set by the Republic of Indonesia Ministry of Health, which is 49/100.000 population per year.
The sub-district with the highest number of DHF cases is Gadingrejo sub-district with 90 cases with DHF occurrence rate of $118,23 / 100.000$ population. Gadingrejo sub-district has a population density of 1.103 population $/ \mathrm{km}^{2}$ and is the area with the second highest population density in Pringsewu District.

The sub-district with the lowest number of DHF cases is North Pagelaran sub-district with 2 cases with the DHF occurrence rate of $12,5 / 100.000$ population. North Pagelaran sub-district is a rural area where most of the area is protected forest. The village in North Pagelaran sub-district is a rural area around a protected forest. Population density in North Pagelaran sub-district is 227 population $/ \mathrm{km}^{2}$ and is the area with the lowest population density in Pringsewu District.

Based on spatial analysis, it is seen that DHF cases in several regions have a clustering pattern and are spread around the main roads. This is consistent with research conducted by Asmahani (2010) in Selangor, Malaysia that the DHF case pattern occurs in groups of NNRatio 0,518 using the Average Nearest Neighbor analysis. ${ }^{11}$ The pattern of DHF cases distribution in groups shows that the environment is heterogeneous, so DHF cases are concentrated in particular places and there is an increase in cases in that place. Mosquito habitat concentration 
probably occurs so that there is an increase in the number of cases with cluster distribution patterns. ${ }^{12}$

Based on spatial analysis, it can be seen that DHF cases in several regions have a clustering pattern and are spread around major roads, especially on roads that connect Lampung Province to Bengkulu Province. People who live close to main national road are likely to contract DHF from viremic individuals who pass through that area. ${ }^{13}$ Based on field observation, there are many workshops around the main road for buses and trucks, and so in those workshops there are many used tires that are stacked without being covered. Those used tires have the potential to become breeding places for mosquitoes when the rainy season arrives. In this research, of the 109 used tires examined, there were 29 that larva positive $(28,16 \%)$. The existence of mosquitos breeding places is a risk factor for DHF occurrence.

Breeding place can be found both inside and outside the house. The main Breeding places inside the house are the bathtub, water reservoirs, plastic containers and flower vases. Whereas the main breeding places outside the house are tree holes, bamboo pieces, leaves base of several types of plants (palm, banana), coconut shell and piles of used objects. ${ }^{14}$ The results if this research indicate that there is a significant relationship between the existence of breeding places and the DHF occurrence rate ( $p$-value $=0,000)$ with a correlation coefficient of 0,357 . The results of this research are consistent with Husna's (2016) research, that there is a relationship between breeding places and the DHF occurrence rate ( $p$-value $=$ $0,016){ }^{15}$

Observation results indicate that the type of breeding places inside the house are bathtub, plastic bucket, and dispenser. Breeding places outside the house are used tires, used goods, water barrels, plastic waste, drinking places for birds and fish ponds. Whereas the natural breeding places are in the form of bamboo pieces, coconut shell and chocolate shell. The existence of breeding places associated with vector density in an area. The more places where mosquitos can breed, the more vectors in that area will be. The increase in number of breeding places increases the risk of the increase in number of DHF cases. Zuhriyah's research (2012) states that bathtubs and tanks for drinking water are the most common places where larvae are found in both urban and rural areas. ${ }^{16}$ Babita's research in India (2019) states that in summer, larvae are more commonly found in breeding places inside the house, whereas in the rainy season, larvae are found mostly in breeding places outside the house and natural breeding places. ${ }^{17}$
Vector density is a risk factor for DHF transmission, the higher the vector density, the higher the risk of people getting DHF. The vector density of DHF can be known by examining $\mathrm{ABJ}, \mathrm{CI}$ and HI. ${ }^{10,18} \mathrm{An}$ area is said to be safe if $\mathrm{ABJ} \geq 95 \%, \mathrm{CI} \leq 5 \%$, and $\mathrm{HI}<5 \%{ }^{10,19}$ The results of the research show that there is a significant relationship between $\mathrm{ABJ}$ and $\mathrm{DHF}$ occurrence rate ( $p$-value $=0,000)$ with a correlation coefficient of $-0,441$. This means that the increase in the value of $\mathrm{ABJ}$ is accompanied by a decrease in the DHF occurrence rate, a strong relationship level. There is a significant relationship between CI and the DHF occurrence rate $(p$-value $=0,000)$ with a correlation coefficient of 0,544 . This means that the increase in Container Index value is accompanied by an increase in the number of DHF occurrence rate, a strong relationship level. There is a significant relationship between $\mathrm{HI}$ and DHF occurrence rate ( $p$-value $=0,000)$ with a correlation coefficient of 0,441 . This means that the increase in House Index value is accompanied by an increase in occurrence rate of DHF, a strong relationship level.

In this research, the highest $\mathrm{ABJ}$ value was $88,89 \%$, the lowest $\mathrm{HI}$ value was $11,11 \%$, while the highest $\mathrm{HI}$ value was $63,64 \%$ and the average CI value was $14,25 \%$. Based on the ABJ, HI and CI values, it can be concluded that Pringsewu District has a high vector density. The more dense the population of Aedes aegypti mosquitos is, the higher the risk of becoming infected with DHF virus is, with a faster spread time so that the number of DHF cases rapidly increases which ultimately results in outbreaks of DHF. In order to reduce vector density, it is necessary to eradicate mosquito nests and check larvae periodically. Nurrochmawati 's research in Indonesia (2017) states that DHF occurrence rate is affected by periodic larvae examination ( $p$-value $<0,001) .^{20}$

Based on observations done in the field, containers with larvae are often found in houses that have bathtubs, because they rarely drain the tubs, but in houses that do not have bathtubs, they rarely find larvae because they store water in plastic buckets where water stored up is used up within a day.

\section{CONCLUSION}

The existence of breeding places associated with the number of DHF occurrence rate ( $p$-value $=0,000)$, the more the number of breeding place in an area is, the higher the occurrence rate of DHF. The vector density measured through $\mathrm{ABJ}, \mathrm{CI}$ and $\mathrm{HI}$ is related to the occurrence rate of DHF ( $p$-value $=0,000)$ and Pringsewu District has a high vector density. Based on the results of the research, the Pringsewu District Health Office should 
be more active in the eradication of mosquito nests through PSN 3M+ and periodic larvae monitoring.

\section{ACKNOWLEDGMENTS}

The authors would like to thank the PPSDMK Ministry of Health of Republic of Indonesia for funding this research. The authors also thank the Pringsewu District Health Office and Bappeda (Agency for Regional Development) for helping during the research.

\section{REFERENCES}

[1] World Health Organization. Comprehensive Guidelines for Prevention and Control of Dengue and Dengue Haemorrhagic Fever. Revised. World Health Organization Regional Office for South-East Asia, editor. New Delhi: WHO Press; 2011.

[2] Hadinegoro SRH, Dkk. Tatalaksana Demam Berdarah Dengue Di Indonesia. Ketiga. Jakarta: Departemen Kesehatan RI; 2004. 68 p.

[3] Dinas Kesehatan Provinsi Lampung. Profil Kesehatan Provinsi Lampung Tahun 2015. Bandar Lampung; 2015.

[4] Dinas Kesehatan Kabupaten Pringsewu. Profil Kesehatan Kabupaten Pringsewu Tahun 2017. Pringsewu; 2017.

[5] World Health Organization. Global Strategy for Dengue Prevention and Control 2012 - 2020. World Health Organization, editor. Genewa: WHO Press; 2012. 35 p.

[6] World Health Organization. Dengue and Severe Dengue. 2014.

[7] World Health Organization. Dengue: Guidelines For Diagnosis, Treatmet, Prevention and Control. New Editio. Paris: WHO Press; 2009.

[8] Handayani D, R.Soelistijadi, Sunardi S. Pemanfaatan Analisis Spasial untuk Pengolahan Data Spasial Sistem Informasi Geografi Pemanfaatan Analisis Spasial untuk Pengolahan Data Spasial. Jurnal Teknologi Informasi DINAMIK. 2005;X(2):108-16.

[9] Setiawan B, Supardi F, Bani VKB. Analisis Spasial Kerentanan Wilayah terhadap Kejadian Demam Berdarah Dengue di Wilayah Kerja Puskesmas Umbulharjo Kota Yogyakarta Tahun 2013. Jurnal Vektor Penyakit. 2017;11(2):77-87.

[10] World Health Organization. Guidelines for Dengue Surveillance and Mosquito Control. Second Edi. Self L, Yap HH, Foo AES, Chong N., editors. Manila; 2003. 1$105 \mathrm{p}$.

[11] Asmahani A, R MNM, Harsuzilawati M. Spatial Mapping of Dengue Incidence: A Case Study in Hulu Langat District , Selangor , Malaysia. International Journal of Environmental, Chemical, Ecological, Geological and Geophysical Engineering. 2010;4(7):251-5.

[12] Boewono DT, Widiarti W, Ristiyanto R. Analisis Spasial Distribusi Kasus Demam Berdarah Dengue (DBD) Kota Bontang, Provinsi Kalimantan Timur. Buletin Penelitian Kesehatan. 2012;40(3):100-9.

[13] Vong S, Khieu V, Glass O, Ly S, Duong V, Huy R, et al. Dengue Incidence in Urban and Rural Cambodia : Results from Population-Based Active Fever Surveillance , 2006 2008. PLOS Neglected Tropical Diseases. 2010;4(11).

[14] World Health Organization. Guidelines For Dengue Surveillance and Mosquito Control. Self L, Yap HH, Foo AE., Chong N., editors. Manila: WHO Regional Publication; 1995.

[15] Husna RN, Wahyuningsih NE, Dharminto D, Murwani R. Mosquito Breeding Place and Container Index are Related to Dengue Hemorrhagic Fever Cases in Uptown Semarang Mosquito Breeding Place and Container Index Are Related to Dengue Hemorrhagic Fever Cases in Uptown Semarang. 2017;(July).

[16] Zuhriyah L, Iy H, Ad B. The Key Container of Aedes aegypti in Rural and Urban Malang, East Java, Indonesia. Health and the Environment Journal. 2012;3(3):51-8.

[17] Bisht B, Kumari R, Nagpal BN, Singh H, Kumar S. Influence of environmental factors on dengue fever in Delhi. International Journal of Mosquito Research. 2019;6(2):11-8

[18] Ong J, Liu X, Rajarethinam J, Yap G, Ho D, Ng LC. A novel entomological index, Aedes aegypti Breeding Percentage, reveals the geographical spread of the dengue vector in Singapore and serves as a spatial risk indicator for dengue. Parasites \& Vectors. 2019;12(17):1-10.

[19] World Health Organization. Vector Surveillance and Control at Ports, Airports, and Ground Crossings. Kumar A, editor. Geneva: WHO Press; 2016.

[20] Nurrochmawati I, Dharmawan R. Biological , Physical , Social, and Environmental Factors Associated with Dengue Hemorrhagic Fever in Nganjuk , East Java. Journal of Epidemiology and Public Health. 2017;2(2):93105. 